\title{
PENGARUH MODEL PEMBELAJARAN TEAM ASISSTED INDIVIDUALIZATION DENGAN MEDIA AUDIOVISUAL TERHADAP KEMAMPUAN BERPIKIR KRITIS SISWA KELAS X SMA NEGERI 2 LOA JANAN KUTAI KARTANEGARA
}

\author{
Mardiani, Elsje Theodora Maasawet, Aloysius Hardoko
}

Universitas Mulawarman

\section{Sejarah Artikel \\ Diterima 1 Oktober 2017 \\ Disetujui 25 Juli 2018 \\ Diterbitkan 1 Agustus 2018}

\section{Kata Kunci}

model pembelajaran, media audiovisual, team assisted individualization, kemampuan berpikir kritis.

\begin{abstract}
Abstrak
Penelitian ini bertujuan untuk mendeskripsikan kemampuan berpikir kritis siswa yang mengikuti pembelajaran dengan model pembelajaran Team Assisted Individualization menggunakan Media Audiovisual dan siswa kelas kontrol yang mengikuti pembelajaran konvensional pada siswa kelas $X$ di Sekolah Menengah Atas Negeri 2 Loa Janan Kabupaten Kutai Kartanegara. Penelitian ini adalah penelitian eksperimen semu (quasi eksperiment) dengan desain penelitian "pre test post test control group design". Populasi penelitian adalah siswa kelas $X$ di Sekolah Menengah Atas Negeri 2 Loa Janan Kabupaten Kutai Kartanegara , dengan sampel 25 orang siswa kelas $X$ IPA 1 sebagai kelas perlakuan dan 25 orang siswa kelas X IPA 2 sebagai kelas kontrol. Metode dalam penelitian ini yaitu tes. Data yang didapatkan dari metode tes dianalisis dengan teknik analisis deskriptif dan statistik dengan rumus Gain Score. Hasil penelitian kemampuan berpikir kritis pada kelas perlakuan dengan rata-rata N-Gain sebesar 0,74 sedangkan rata-rata skor $N$-Gain pada kelas konvensional sebesar 0,54. Pengujian hipotesis menggunakan Gain Score menunjukkan kemampuan berpikir kritis pada kelas perlakuan lebih tinggi daripada kemampuan berpikir kritis siswa kelas kontrol. Kesimpulan hasil penelitian ini adalah bahwa penerapan model pembelajaran Team Assisted Individualization dengan Media Audiovisual berpengaruh terhadap kemampuan berpikir kritis pada siswa kelas X SMA Negeri 2 Loa janan Kutai Kartanegara.

\section{Cara Mengutip}

Mardiani, Maasawet, E.T., Hardoko, A. (2018). Pengaruh Model Pembelajaran Team Asissted Individualization dengan Media Audiovisual terhadap Kemampuan Berpikir Kritis Siswa Kelas X SMA N 2 Loa Janan Kutai Kartanegara. DWIJA CENDEKIA: Jurnal Riset Pedagogik, 2 (1), 32-42
\end{abstract}

Korespondensi Penulis

mardianisman1loajanan@gmail.com
p-ISSN 2581-1843 e-ISSN 2581-1835 


\section{PENDAHULUAN}

Salah satu masalah pokok dalam pembelajaran pada pendidikan formal (sekolah) dewasa ini adalah masih rendahnya daya serap siswa. Hal ini nampak dari rerata hasil belajar siswa yang senantiasa masih sangat memprihatinkan. Selain secara empiris, berdasarkan hasil analisis penelitian terhadap rendahnya hasil belajar siswa, hal tersebut disebabkan proses pembelajaran yang didominasi oleh pembelajaran tradisional. Pada pembelajaran ini kelas cenderung teacher center, sehingga siswa pasif. Guru hanya menjelaskan konsepkonsep yang ada pada buku ajar atau referensi lain, tanpa dilakukan startegi pendekatan pembelajaran yang lebih inovatif.

$$
\text { Kosasih (2014) menyatakan }
$$

peranan guru adalah memberikan kemudahan-kemudahan yakni dengan mengembangkan susasana belajar yang memberi kesempatan siswa unuk menemukan ,menerapkan ideide mereka sendiri dalam belajar.Bagi siswa pembelajaran harus bergeser dari " diberi tahu " menjadi aktif mencari tahu ".

Hasil observasi lainnya dan analisis kebutuhan yang dilakukan di SMA Negeri 2 Loa Janan Kutai Kartanegara menunjukkan bahwa pembelajaran yang diterapkan menggunakan pendekatan teacher center, siswa masih kurang berani untuk mengemukakan pendapat ataupun bertanya kepada guru ketika ada materi yang belum dipahami, siswa merasa kesulitan dengan materi tertentu yang didalamnya terdapat proses perlu pemahaman lebih tinggi, hasil belajar siswa masih rendah, dan sebagian besar siswa merasa jenuh, bosan dan kurang antusias dan kurang memiliki kemampuan berpikir kritis ketika belajar Biologi.

Tujuan pendidikan adalah membentuk siswa kreatif, kritis dan inovatif. Individu yang suka menemukan hal-hal baru, Individu yang suka menemukan alternatif agar mampu membuat pilihan dan manusia yang tidak menerima apa saja informasi yang diberikan kepadanya tanpa membuktikan kebenarannya terlebih dahulu. Individu yang dimaksud dalam hal ini adalah siswa.

Kemampuan berpikir siswa yang rendah dapat disebabkan karena strategi yang diterapkan guru dalam pembelajaran belum berorientasi pada pemberdayaan berpikir tingkat tinggi siswa dan hanya menekankan pada pemahaman konsep.

Pembelajaran di kelas diarahkan tidak semata-mata pada penguasaan dan pemahaman konsep-konsep ilmiah, tetapi juga pada peningkatan kemampuan dan berpikir siswa, khususnya kemampuan berpikir tingkat tinggi. Artinya, guru perlu mengajarkan siswanya untuk belajar berpikir (teaching of thinking) sehingga dalam proses pembelajaran guru harus memiliki teknik dan strategi mengajar yang baik agar tercipta suasana yang efektif, kondusif, menarik, dan menyenangkan bagi siswa yang memudahkan siswa dalam menerima informasi yang diberikan. Proses pelaksanaan pembelajaran Biologi di kelas, siswa kurang belajar lebih aktif, kreatif dan tidak mandiri. Separuh lebih dari jumlah siswa di kelas tersebut tidak melakukan sesuatu untuk mengembangkan dirinya dan rasa ingin tahu siswa cenderung rendah terhadap materi yang sedang diajarkan, hal tersebut dapat dilihat dari hasil pengamatan 
yang dilakukan di kelas, siswa merasa cuek ketika mengikuti proses pembelajaran. Siswa malah ribut dan asik bermain sendiri ketika proses pembelajaran berlangsung, sehingga ketika ditanya siswa tidak bisa menjawab, dan kalaupun bisa menjawab jawaban tersebut terkadang menyimpang dari pertanyaan guru. Apabila hal tersebut berjalan terus menerus, maka dapat mengakibatkan daya berfikir siswa menjadi rendah yang membuat siswa tidak mampu untuk mengembangkan dirinya untuk lebih kritis dalam berpikir.

Salah satu alternatif model pembelajaran yang dapat mengaktifkan siswa di dalam kelas yaitu dengan menerapkan pembelajaran Team Assisted Individualization. Pembelajaran model Team Assisted Individualiztion merupakan model pembelajaran yang mempunyai strategi pembelajaran bimbingan antar teman atau tutor teman sebaya. Team Assisted Individualization menggabungkan pembelajaran kooperatif dengan pengajaran individual (Supriyono, 2007).

Team Assisted Individualization menggabungkan antara metode pembelajaran kooperatif dengan dan pembelajaran klasikal berbasis individual, bantuan individu dalam kelompokni mendorong siswa untuk berpikir baik secara individu maupun dalam suatu tim kompetitif pada tim kelompok siswa (Slavin, 2005).

Penggunaan media audio visual, tidak hanya akan menggunakan indra penglihatan tapi siswa juga dapat menggunakan indra pendengaran. Belajar menggunakan indra penglihatan dan pendengaran akan memberikan keuntungan bagi siswa dalam memahami materi pembelajaran. Berdasarkan penuturan di atas, peneliti tertarik untuk mengadakan penelitian dengan berbantukan media audiovisual. Tentunya hal ini sedikit banyaknya dapat meningkatkan rasa ingin tahu siswa jauh lebih besar terhadap materi ekosistem dan secara tidak langsung akan berpengaruh terhadap kemampuan berpikir kritis siswa dalam pembelajaran Biologi.

\section{METODE PENELITIAN}

Jenis penelitian ini adalah penelitian eksperimen semu atau "quasi experiment" Kuantiatif yang digunakan untuk meneliti pada kondisi objek yang alamiah,dimana peneliti sebagai instrument kunci, pengambilan sampel sumber data dilakukan secara purposive, tekhnik pengumpulan data dengan trianggulasi dan hasil penelitian lebih menekankan makna daripada kesimpulan. Penelitian ini dilakukan untuk mengetahui Pengaruh Penggunaan model pembelajaran Team Assisted Individualization dengan Media Audiovisual ditinjau dari kemampuan berpikir kritis dan hasil belajar kognitif siswa kelas $\mathrm{X}$ SMA Negeri 2 Loa Janan kabupaten Kutai Kartanegara. Penelitian ini dilaksanakan di kelas X SMA Negeri 2 Loa Janan Kabupaten Kutai kartanegara. Penelitian dilakukan pada semester genap tahun pelajaran 2016 / 2017. Populasi dalam penelitian ini adalah seluruh siswa kelas X SMA Negeri 2 Loa Janan Kabupaten Kutai kartanegara, sedangkan sampel penelitian adalah siswa kelas X IPA 1 sebagai kelas 
perlakuan dan siswa kelas X IPA 2 sebagai kelas kontrol.

Kemampuan berpikir kritis siswa dianalisis secara deskriptif serta dapat diketahui perkembangannya ketika proses pembelajaran berlangsung pada setiap pertemuan. Untuk mengetahui besarnya peningkatan kemampuan berpikir kritis pembelajaran Biologi pada materi ekosistem antara kelas kontrol dan kelas perlakuan dari skor pre test dan post tes peneliti menggunakan rumus Normalized Gain by Hake yaitu:

$$
g=\frac{\text { Skor pos tes-Skor pre tes }}{\text { Skor maksimum-Skor pretes }}
$$

Tabel 1. Klasifikasi Normalisasi Gain

\begin{tabular}{cc}
\hline $\begin{array}{c}\text { Koefisien Normalisasi } \\
\text { Gain }\end{array}$ & Klasifikasi \\
$\mathrm{g}<0,3$ & Rendah \\
$0,3 \leq \mathrm{g}<0,7$ & Sedang \\
$\mathrm{g} \geq 0,7$ & Tinggi \\
\hline
\end{tabular}

Sumber : Hake (1998)

\section{PEMBAHASAN}

Pada kemampuan berpikir siswa, pada rata-rata hasil pretest dan posttest sama dengan data pretes dan posttest hasil belajar,tapi analisis data menggunakan Gain Score untuk menggambarkan perbandingan kemampuan sikap kritis siswa dalam proses pembelajaran. Analisis kemampuan berpikir kritis siswa.

Uji peningkatan hasil kemampuan berpikir kritis siswa bertujuan untuk mengetahui berapa besar peningkatan kemampuan berpikir kritis siswa sebelum diberi perlakuan dan setelah mendapatkan perlakuan yaitu kelas perlakuan yang menggunakan model pembelajaran Team Assisted Individualization dengan Media Audiovisual. Peningkatan kemampuan berpikir kritis siswa dalam pembelajaran Biologi dapat dihitung menggunakan rumus gain ternormalisasi ( $\mathrm{N}$ gain) by Hake (1998), data disajikan pada tabel

Tabel 2. Deskripsi Kemampuan Berpikir Kritis Siswa

\section{kelas}

\begin{tabular}{ccccccc} 
& \multicolumn{3}{c}{ Perlakuan } & \multicolumn{3}{c}{ Kontrol } \\
\cline { 2 - 7 } Statistik & Pretest & Posttest & N-Gain & Pretest & posttest & N-gain \\
Jumlah Siswa & 25 & 25 & - & 25 & 25 & - \\
Skor ideal & 40 & 40 & 0 & 40 & 40 & 0 \\
Maksimum & 20 & 36 & 0,8 & 16 & 26 & 0,3 \\
$\quad$ (X max) & & 25 & 0,53 & 10 & 15 & 0,16 \\
Minimum & 8 & 31,5 & 0,77 & 12,8 & 21,7 & 0,54 \\
$\quad$ (X min ) & 12,6 & 7,6 & & 7,64 & 8,7 & \\
Rata-rata & 5,4 & & & & & \\
Simpangan & & & & &
\end{tabular}


Berdasarkan tabel di atas dapat dilihat bahwa selisih rata-rata pretest dan posttest kelas perlakuan yaitu 18,9 lebih besar daripada selisih rata-rata pretest dan posttest kelas konvensional yaitu 8,8.Jika dilihat dari simpangan baku skor posttest kelas eksperimen lebih besar daripada skor pretestnya, hal ini menunjukkan bahwa skor kemampuan berpikir kritis pembelajaran Biologi setelah diterapkan model pembelajaran Team Assisted Individualization dengan menggunakan Media Audiovisual lebih bervariasi dan menyebar pada rata-rata kelas .Sedangkan simpangan baku skor post test kelas konvensional lebih kecil dari skor pretest, ini menunjukkan bahwa skor kemampuan berpikir belajar Biologi sebelum menggunakan dengan model konvensional lebih menyebar terhadap rata-rata kelas.

Data di atas, hasil rata-rata posttest sebesar pada kelas perlakuan 84,66 lebih tinggi bila dibandingkan kelas kontrol yang memiliki nilai 67,6 . Rata-rata hasil posttest dengan skor lebih tinggi terdapat pada kelas perlakuan dibandingkan kelas kontrol menunjukkan bahwa tingkat kemampuan berpikir kritis belajar siswa lebih baik setelah diberikan perlakuan penerapan model pembelajaran Team Assisted Individualization dengan Media Audiovisual pada materi ekosistem. Peningkatan kemampuan berpikir kritis siswa dalam belajar tersebut dapat dilihat pada gambar 1.

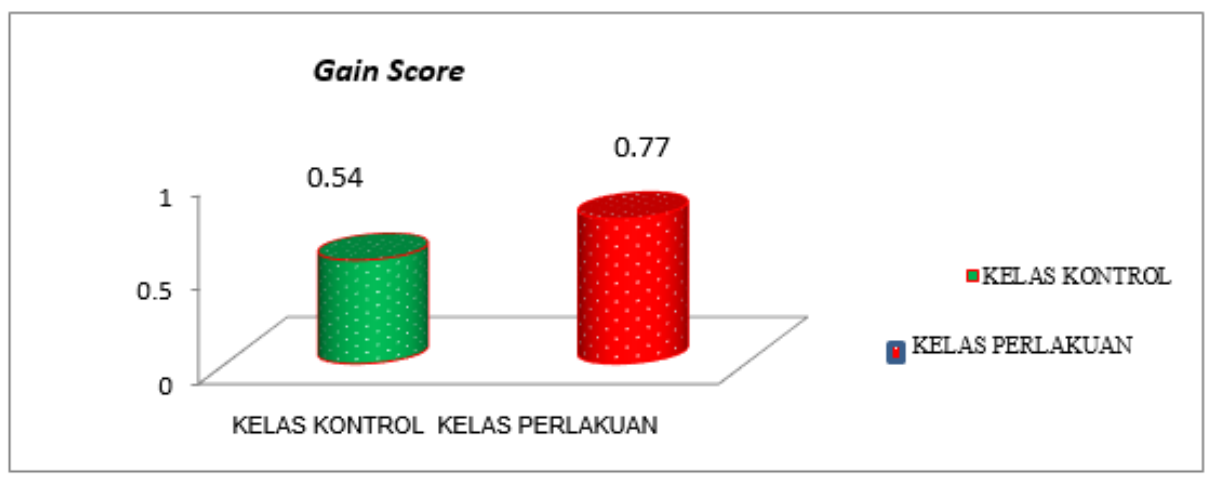

Gambar 1. Diagram Kemampuan Berpikir Kritis

Berdasarkan gambar 1 dapat dilihat bahwa skor maksimum antara kelas kontrol dan perlakuan sama yaitu 20, hal itu berarti antara kedua kelas perlakuan memiliki kemampuan awal berpikir kritis yang sama untuk siswanya.

Jika dilihat dari simpangan baku kelas kontrol lebih besar dari kelas eksperimen, ini menunjukkan bahwa skor kemampuan berpikir kritis pembelajaran biologi pada kelas kontrol lebih bervariasi dan menyebar pada tiap rata-rata kelas, sedang skor kelas perlakuan lebih mengelompok kemampuan berpikir kritis siswanya.

Sebelum menguji perbedaan rata-rata kedua kelompok tersebut dengan menggunakan analisis Independent Sample $T$ test, diperlukan uji normalitas dan homogenitas terlebih dahulu. 
Tabel 3. Uji Normalitas Pretest

Tests of Normality

\begin{tabular}{cccc} 
Faktor & \multicolumn{3}{c}{ Kolmogorov-Smirnov a $^{\mathrm{a}}$} \\
Pretest Perlakuan & .173 & 25 & .053 \\
Pretest Kontrol & .134 & 25 & $.200^{*}$
\end{tabular}

Hasil tabel 2 uji normalitas di atas diperoleh untuk hasil pretest kelas perlakuan nilai signifikan $p=0,35$, sehingga $p>a$ dan untuk kelas kontrol nilai signifikasi $\mathrm{p}=0,44$ ,sehingga $p>\alpha$, dengan demikian sampel berasal dari populasi yang berdistribusi normal

\section{Tabel 4. Uji Homogenitas Pre test Kemampuan Berpikir Kritis}

Test of Homogeneity of Variances

\begin{tabular}{rrrr}
\hline $\begin{array}{l}\text { Pre test } \\
\text { Levene Statistic }\end{array}$ & df1 & df2 & Sig. \\
\hline .709 & 1 & & \\
\hline
\end{tabular}

Pengujian

normalitas

dan

Hasil uji homogenitas dengan menggunakan uji Levene pada taraf signifikan $\alpha=0,05$ menunjukkan data skor pretest kemampuan berpikir kritis siswa dalam belajar Biologi pada kelas perlakuan dan kelas kontrol adalah homogen. Nilai signifikasi yang terterra pada hasil pengujian homogenitas taraf sifnifikasi adalah 0,404 lebih besar dari nilai $\alpha 0,05$. homogenitas telah menunjukkan hasil pretest kemampuan berpikir kritis siswa pada pembelajaran Biologi untuk kelas perlakuan dan kelas kontrol berdistribusi normal dan varian kedua kelompok juga homogen, oleh karena itu pengujian dua rata - rata dapat dilakukan dengan cara menggunakan analisis Independent Sampel $t$ Test. Hasil pengolahan data tersebut disajikan dalam tabel table 5 
Tabel 5. Hasil Uji Perbedaan Rata-rata Preetest kelas Perlakuan dan kelas Kontrol

\begin{tabular}{|c|c|c|c|c|c|}
\hline \multicolumn{6}{|c|}{ Independent Samples Test } \\
\hline & \multicolumn{3}{|c|}{$\begin{array}{c}\text { Levene's Test for Equality of } \\
\text { Variances }\end{array}$} & \multicolumn{2}{|c|}{ t-test for Equality of Means } \\
\hline Kemampuan & $\begin{array}{c}F \\
950\end{array}$ & $\begin{array}{l}\text { Sig. } \\
335\end{array}$ & $\begin{array}{c}t \\
824\end{array}$ & $\begin{array}{l}\mathrm{df} \\
48\end{array}$ & $\begin{array}{c}\text { Sig. (2-tailed) } \\
414\end{array}$ \\
\hline $\begin{array}{l}\text { Berpikir Kritis } \\
\text { Belajar Biologi }\end{array}$ & & & .824 & 47.39 & .414 \\
\hline
\end{tabular}

Hasil uji perbedan rata-rata pretest kelas Perlakuan dan kelas kontrol untuk kemampuan berpikir kritis belajar Biologi menunjukkan menerima Ho, artinya tidak tidak terdapat perbedaan rata-rata awal kemampuan berpikir kritis belajar Biologi siswa di kelas perlakuan dan kelas kontrol, hal ini didapat berdasarkan nilai sig (2-tailed) 0,41 lebih besar dari nilai $\alpha=0,05$.

Berdasarkan Tabel 1 dapat dilihat bahwa skor maksimum kedua kelas sama yaitu 40 . Skor minimum pada kelas kontrol yaitu sebesar 15 dan pada kelas perlakuan sebesar 25, lebih besar 10 angka, hal tersebut berarti siswa yang memiliki skor terendah terdapat pada kelas konvensional. Skor rata-rata kelas perlakuan lebih tinggi daripada kelas kontrol, selisih rata-rata kedua kelas adalah sebesar 9,8.

Dilihat dari simpangan baku, simpangan baku kelas kontrol lebih besar dari kelas perlakuan, ini menunjukkan bahwa skor kemampuan berpikir kritis dalam pembelajaran Biologi pada kelas kontrol lebih bervariasi dan menyebar terhadap rata-rata kelas, sedangkan skor kelas perlakuan lebih mengelompok.

Sebelum menguji perbedaan rata-rata kedua kelompok tersebut dengan menggunakan analisis Independent Sampel $T$ Tes, diperlukan uji normalitas dan homogenitas terlebih dahulu.

Tabel 6. Hasil Uji Normalitas Posttest Pada kelas Perlakuan dan Kelas Kontrol

\section{Tests of Normality}

\begin{tabular}{ccccc} 
& Faktor & \multicolumn{2}{c}{ Kolmogorov-Smirnov $^{\mathrm{a}}$} \\
\cline { 2 - 5 } Kemampuan Berpikir \\
\cline { 2 - 5 } Kritis & Kelas Perlakuan & .197 & 25 & .322 \\
& Kelas kontrol & .177 & 25 & .128 \\
\hline
\end{tabular}

Pada tabel 6 diperoleh hasil uji normalitas pada taraf signifikansi $\alpha$ $=0,05$ menunjukkan untuk kelas eksperimen nilai signifikan $p=0,32$ sehingga sampel berdisribusi normal dan untuk kelas kontrol nilai signifikansi $p=0,128$ sehingga $p>$ a. Dengan demikian sampel berasal dari populasi yang berdistribusi normal. Hal ini didapat dengan membandingkan nilai signifikansi hasil perhitungan a yang telah ditetapkan. 
Pengujian perbedaan dua rata-rata menggunakan analisis Independen sampel $t$ test. Data

hasil perhitungan disajikan pada tabel 7.

Tabel 7. Tabel Uji Independen Sampel T-Tes

\begin{tabular}{|c|c|c|c|c|}
\hline \multicolumn{5}{|c|}{ Group Statistics } \\
\hline $\begin{array}{l}\text { kemampuan } \\
\text { Berpikir kritis }\end{array}$ & $\begin{array}{c}\text { Faktor } \\
\text { Kelas } \\
\text { Perlakuan } \\
\text { kelas } \\
\text { kontrol }\end{array}$ & $\begin{array}{l}\mathrm{N} \\
25 \\
25\end{array}$ & $\begin{array}{c}\text { Mean } \\
84.640 \\
0 \\
63.840 \\
0\end{array}$ & $\begin{array}{c}\text { Std. } \\
\text { Deviation } \\
5.39197\end{array}$ \\
\hline
\end{tabular}

Pada tabel di atas rata- rata kemampuan berpikir kritis Biologi siswa yang diajar menggunakan model pembelajaraan Team Assisted Individualization menggunakan Media Audiovisual sebesar 84.64 dengan standart deviasi 0,53 serta model pembelajaran konvensional sebesar 61,8 standar deviasi sebesar 0,87. Hal ini berarti secara deskriptif kemampuan berpikir siswa di kelas perlakuan yang diajar dengan model pembelajaran Team Assisted Individualization menggunakan Media Audiovisual lebih tinggi daripada pembelajaran konvensional di kelas kontrol. Mengetahui membandingkan kualitas peningkatan kemampuan berpikir kritis pada pembelajaran Biologi setelah diberikan perlakuan menggunakan model pembelajaran Team Assisted Individualization menggunakan Media Audiovisual, maka dilakukan pengujian menggunakan analisis gain ternormalisasi (Normalized Gain).

Berdasarkan tabel 1 dapat dilihat dapat dilihat bahwa skor peningkatan maksimum kelas perlakuan lebih tinggi daripada skor maksimum kelas kontrol. Skor peningkatan minimum pada kelas kontrol yaitu sebesar 0,16 dan skor minimum pada kelas eksperimen sebesar 0,53 lebih besar, hal itu berarti siswa yang memiliki peningkatan tertinggi terdapat pada kelas perlakuan sedangkan siswa yang memilikki peringkat terendah terdapat pada kelas kontrol. Skor rata-rata peningkatan kelas perlakuan lebih tinggi daripada kelas kontrol selisih ratarata kedua kelas tersebut adalah 0,23 .

Dilihat dari simpangan baku, kelas kontrol lebih besar daripada simpangan baku kelas Perlakuan ,ini menunjukkan bahwa skor kemampuan berpikir kritis pada proses pembelajaran Biologi pada kelas kontrol lebih bervariasi dan menyebar terhadap rata-rata kelas, sedangkan skor kelas Perlakuan lebih mengelompok.

Mengetahui kemampuan berpikir siswa per indikator, peneliti menggunakan Lembar kerja peserta didik (LKPD) yang dirancang khusus sesusia dengan indikator-indikator yang terdapat dalam rumusan kemampuan berpikir kritis. Pada kelas kontrol peneliti tidak memberikan LKPD, namun soal yang diberikan pada 
kelas control sama dengan soalsoal yang terdapat pada kelas perlakuan, tapi hanya sebagai soal latihan dan dikerjakan secara individu.

Perbandingan kemampuan berpikir kritis siswa dalam pembelajaran Biologi antara kelas Perlakuan dan kelas kontrol berasal dari hasil skor LKPD yang dikerjakan siswa berdasarkan indikator disajikan dalam tabel 8.

Tabel 8. Perbandingan Kemampuan Berpikir Kritis Siswa Antara Kelas Perlakuan dan Kelas Kontrol Berdasarkan Indikator.

\begin{tabular}{ccccccc}
\hline & & \multicolumn{2}{c}{ Perlakuan } & \multicolumn{2}{c}{ Kontrol } \\
\cline { 4 - 6 } No & Indiktor & $\begin{array}{l}\text { Skor } \\
\text { ideal }\end{array}$ & $\begin{array}{l}\text { Rata- } \\
\text { rata } \\
\text { Skor }\end{array}$ & $\begin{array}{l}\text { Prosent } \\
\text { ase }\end{array}$ & $\begin{array}{l}\text { Jumla } \\
\mathbf{h} \\
\text { skor }\end{array}$ & $\begin{array}{l}\text { Prosent } \\
\text { ase }\end{array}$ \\
\cline { 4 - 7 } 1 & $\begin{array}{c}\text { Mengidenfikasi } \\
\text { Permasalahan }\end{array}$ & 15 & 8,8 & $59 \%$ & $2,2 \%$ & $14,6 \%$ \\
2 & $\begin{array}{c}\text { Memberikan } \\
\text { Argumen }\end{array}$ & 20 & 14,8 & $72 \%$ & $2,4 \%$ & $12 \%$ \\
3 & Deduksi & 20 & 15,6 & $78 \%$ & 2,7 & $13,3 \%$ \\
4 & Evalusi & 20 & 15 & $75 \%$ & 2,4 & $12 \%$ \\
5 & $\begin{array}{c}\text { Mengatur } \\
\text { Stategi (taktik) }\end{array}$ & 25 & 19,8 & $76,8 \%$ & 2,3 & $9,3 \%$ \\
\hline
\end{tabular}

Tabel 8 menunjukkan bahwa terdapat perbedaan perolehan skor nilai atau prosentase kemampuan berpikir kritis siswa per indikator antara kelas Perlakuan dan kelas kontrol, Hal ini terlihat dari rata - rata perolehan skor per indikator kemampuan berpikir kritis siswa pada kelas perlakuan lebih tinggi dan berbeda sangat jauh daripada kelas kontrol

\section{SIMPULAN}

Tujuan pendidikan adalah membentuk siswa kreatif, kritis dan inovatif. Individu yang suka menemukan hal-hal baru, individu yang suka menemukan alternatif agar mampu membuat pilihan dan manusia yang tidak menerima apa saja informasi yang diberikan kepadanya tanpa membuktikan kebenarannya terlebih dahulu. Individu yang dimaksud dalam hal ini adalah siswa.
Keterampilan berpikir siswa yang rendah dapat disebabkan karena strategi yang diterapkan guru dalam pembelajaran belum berorientasi pada pemberdayaan berpikir tingkat tinggi siswa, dan hanya menekankan pada pemahaman konsep.

Pembelajaran di kelas diarahkan tidak semata-mata pada penguasaan dan pemahaman 
konsep-konsep ilmiah, tetapi juga pada peningkatan kemampuan dan berpikir siswa, khususnya kemampuan berpikir tingkat tinggi. Artinya, guru perlu mengajarkan siswanya untuk belajar berpikir (teaching of thinking) sehingga dalam proses pembelajaran guru harus memiliki teknik dan strategi mengajar yang baik agar tercipta suasana yang efektif, kondusif, menarik, dan menyenangkan bagi siswa yang memudahkan siswa dalam menerima informasi yang diberikan. Dalam pelaksanaan pembelajaran biologi di kelas, siswa kurang belajar lebih aktif, kreatif dan tidak mandiri. Separuh lebih dari jumlah siswa di kelas tersebut tidak melakukan sesuatu untuk mengembangkan dirinya dan rasa ingin tahu siswa cenderung rendah terhadap materi yang sedang diajarkan, hal tersebut dapat dilihat dari hasil pengamatan yang dilakukan di kelas, siswa merasa cuek ketika mengikuti proses pembelajaran. Siswa malah ribut dan asik bermain sendiri ketika proses pembelajaran berlangsung, sehingga ketika ditanya siswa tidak bisa menjawab, dan kalaupun bisa menjawab jawaban tersebut terkadang menyimpang dari pertanyaan guru. Apabila hal tersebut berjalan terus menerus, maka dapat mengakibatkan daya berfikir siswa menjadi rendah yang membuat siswa tidak mampu untuk mengembangkan dirinya untuk lebih kritis dalam berpikir.

Salah satu alternatif model pembelajaran yang dapat mengaktifkan siswa di dalam kelas yaitu dengan menerapkan pembelajaran Team Assisted Individualization. Pembelajaran model Team Assisted Individualiztion merupakan model pembelajaran yang mempunyai strategi pembelajaran bimbingan antar teman atau tutor teman sebaya. Team Assisted Individualization menggabungkan pembelajaran kooperatif dengan pengajaran individual

Unsur dalam Team Assisted Individualization yang memungkinkan dapat meningkatkan kemampuan berpikir kritis adalah pada saat belajar individu siswa dilatih untuk mengidentifikasi suatu permasalahan serta membuat langkah penyelesaian pada saat diskusi kelompok, siswa saling bertukat pendapat untukmenyelesaikan suatu masalah siswa diharuskan bertanggungjawab atas semua pengecekan jawaban yangdikerjakan oleh teman satu kelompoknya. Pada saat pengecekan itu siswa dilatih untuk berpikir kritis untuk menganalisa jawaban temannya dan menarik kesimpulan mana jawaban yang benar dan mana jawaban yang salah

\section{DAFTAR PUSTAKA}

Amirono. (2016). Evaluasi Dan Arnyana. (2007). Pengaruh Penilaian. Malang: Gava Media.

Penerapan Model PBL Dipandu Strategi Kooperatif Terhadap Kecakapan Berpikir Kritis Siswa

Arikunto, S. (2010). Manajemen SMA Pada Mata Pelajaran Penelitian. Jakarta: Rineka Cipta

Biologi. Jurnal Pendidikan dan Pengajaran IKIP Negeri Singaraja, Vol. 649. 
Arthana. (2010). Pelajaran Inovatif Berbasis Deef Dialoque/ Critical Thinking. Jurnal Teknnologi Pendidikan, $16: 21$

Ennis, R. H. (2011). The Nature of Critical Thinking: An Outline of Critical Thinking ,(http://faculty.education.illinois. edu/rhennis/documents/The Nature of Critical

Thinking_51711_000.pdf), diakses 23 Desember 2016

Hake. (1998). Analyzing Change/Gain Scores.

http://www.physics.indiana.edu/ sdi/ Analyzing ChangeGain.pdf, diakses 5 Mei 2017

Harissa. http://harissamardiana.blogspot.co.id/2013/05 /ketrampilan-berpikir-kritis cara.html, diakses 2 januari 2017.
Miftahul, H. (2013), Model - model Pembelajaran. Malang: Pustaka Belajar.

Harsono, R. (2005). Melatih Anak Berpikir Analitis, Kritis dan Kreatif. Semarang: Grasindo.

Slavin, R. E. (2005). Cooerative Learning (Teori,Riset dan Praktek) diterjemahkan Narulita Yusron. Bandung: Raja Grafindo Persada.

Sutrisno, Joko. (2010). Menggunakan Ketrampilan Berpikir untuk Meningkatkan Mutu Pembelajaran. (http://www.scribd.com/doc/5497 7805/artikel-erlangga) diakses 26 Januari 2017.

Wisudawati. A, W. \& Sulistyowati, E. (2013). Metodologi Pembelajaran IPA. Jakarta: Bumi Aksara 